\title{
Fly Ash Coated with Magnetic Materials: Improved Adsorbent for Cu (II) Removal from Wastewater
}

\author{
Maria Harja ${ }^{1}\left(\mathbb{D}\right.$, Gabriela Buema ${ }^{2, *}$, Nicoleta Lupu ${ }^{2} \mathbb{D}$, Horia Chiriac ${ }^{2}$, Dumitru Daniel Herea ${ }^{2}$ \\ and Gabriela Ciobanu ${ }^{1, *}$
}

1 Chemical Engineering Department, Faculty of Chemical Engineering and Environmental Protection, "Gheorghe Asachi" Technical University of Iasi, 73 Prof.dr.doc. Dimitrie Mangeron Street, 700050 Iasi, Romania; mharja@tuiasi.ro

2 National Institute of Research and Development for Technical Physics, 47 Mangeron Boulevard, 700050 Iasi, Romania; nicole@phys-iasi.ro (N.L.); hchiriac@phys-iasi.ro (H.C.); dherea@phys-iasi.ro (D.D.H.)

* Correspondence: gbuema@phys-iasi.ro (G.B); gciobanu@tuiasi.ro (G.C)

Citation: Harja, M.; Buema, G.; Lupu, N.; Chiriac, H.; Herea, D.D.; Ciobanu, G. Fly Ash Coated with Magnetic Materials: Improved Adsorbent for $\mathrm{Cu}$ (II) Removal from Wastewater. Materials 2021, 14, 63. https:// dx.doi.org/10.3390/ma14010063

Received: 26 November 2020 Accepted: 21 December 2020 Published: 25 December 2020

Publisher's Note: MDPI stays neutral with regard to jurisdictional claims in published maps and institutional affiliations.

Copyright: () 2020 by the authors. Licensee MDPI, Basel, Switzerland. This article is an open access article distributed under the terms and conditions of the Creative Commons Attribution (CC BY) license (https: / / creativecommons.org/ licenses/by/4.0/).

\begin{abstract}
Fly ash/magnetite material was used for the adsorption of copper ions from synthetic wastewater. The obtained material was characterized by scanning electron microscopy (SEM), energy dispersive X-ray analysis (EDAX), X-ray diffractometer (XRD), Fourier transform infrared spectroscopy (FTIR), Brunauer-Emmett-Teller (BET) surface area, and vibrating sample magnetometer (VSM). Batch adsorption experiments were employed in order to investigate the effects of adsorbent dose, initial $\mathrm{Cu}$ (II) concentration and contact time over adsorption efficiency. The experimental isotherms were modeled using Langmuir (four types of its linearization), Freundlich, Temkin, and Harkins-Jura isotherm models. The fits of the results are estimated according to the Langmuir isotherm, with a maximum adsorption capacity of $17.39 \mathrm{mg} / \mathrm{g}$. The pseudo-second-order model was able to describe kinetic results. The data obtained throughout the study prove that this novel material represents a potential low-cost adsorbent for copper adsorption with improved adsorption capacity and magnetic separation capability compared with raw fly ash.
\end{abstract}

Keywords: copper ions adsorption; $\mathrm{Fe}_{3} \mathrm{O}_{4}$; fly ash; isotherms; kinetic models; wastewater

\section{Introduction}

The discharge of wastewater that contains heavy metals into aquatic environments is one of the most common sources of environmental pollution and is the reason why vital ecosystems are often affected [1,2].

Copper ions are one of the most widespread metals used in industry [3]. Among the three forms in which copper can be found, $\mathrm{Cu}^{2+}$ is considered to be the most toxic $[4,5]$, leading to negative impacts on human health and the environment [6-8]. The allowable limit of copper ions in drinking water was established by World Health Organization at $2 \mathrm{mg} / \mathrm{L}$. On the other hand, according to the United State Environmental Protection Agency (USEPA), the maximum copper concentration in industrial water is recommended to be $1.3 \mathrm{mg} / \mathrm{L} \mathrm{[9].}$

A variety of technologies have been applied for the treatment of waters contaminated with copper ions, among which the adsorption process is considered the most favorable alternative [10-14]. A series of materials were involved in $\mathrm{Cu}$ (II) adsorption, such as fly ash (FA) and modified fly ash [15,16], manganese ore [17], LSX zeolite [18], zeolite 4A [19], mesoporous silica [20], macro algae [21], and chitosan-based biodegradable composite [22]. Different methods have been developed for obtaining adsorbent materials, such as coprecipitation, chemical vapor depositions, plasma, electro-depositions, sol-gel, and ball milling. Of these methods, ball milling has the benefits of simplicity, low-cost, time-saving, no waste generation (water or solvent), ease of application, and possibility to be scaled up to the industrial level. [23]. 
Fly ash is preferred as an adsorbent since it is a cheap and highly-available material $[24,25]$. On the other hand, there are highlights that the presence of fly ash discharged from thermal power plants by the burning of coal represents a big environmental issue [26-29]. Unmodified fly ash presents small adsorption capacities. This fact could be explained through low surface area; hence, it is recommended to find a solution in order to remediate this problem. On the other hand, FA suspended in wastewater cannot be separated from the medium due to its too small particle size. Currently, the recycling of adsorbents is an actual issue [1] in the recovery process that is performed by centrifugation; unfortunately, this process exhibits high costs and energy consumption. A feasible alternative that would overcome these disadvantages consists of the use of magnetic adsorbents [30], with quick separation from wastewater [31].

$\mathrm{Fe}_{3} \mathrm{O}_{4}$ nanoparticles were utilized in a synthesis of various adsorbents due to some advantageous characteristics, such as the presence of surface functional groups, magnetic response ability, small particle size, biocompatibility, and biodegradability [32]. Thus, the obtaining of a new material based on the insertion of $\mathrm{Fe}_{3} \mathrm{O}_{4}$ and $\mathrm{Fe}_{2} \mathrm{O}_{3}$ within fly ash represents an interesting research field and a promising pathway to overcome these environmental problems.

The new material obtained by inserting $\mathrm{Fe}_{3} \mathrm{O}_{4}$ into fly ash particles can be used as adsorbent in wastewater treatment due to some advantages, such as its maximal number of active sites, its high surface area, and its high porosity. It is quickly separated from the solution by an external magnetic field without the use of supplementary steps such as filtration or centrifugation.

An important property to note is that the magnetic adsorbents, the core of which is a cluster of magnetic nanoparticles, do not show remanent magnetization. By removing the magnetic field, these adsorbents can be easily re-suspended in another solution. The adsorption-desorption processes can be performed due to this property. It should also be pointed out that secondary effluents are not generated [33,34].

The functional groups from the structure of unmodified fly ash would become active after combining with magnetite particles, thus yielding in a higher adsorption capacity of the synthesized materials. Also, the obtained material can be considered as a low-cost adsorbent.

The main objective of this paper was to obtain a low-cost and a very efficient magnetic adsorbent based on fly ash combined with $\mathrm{Fe}_{3} \mathrm{O}_{4}$ by a green method as well as to investigate the ability of the obtained composite to remove copper ions from synthetic wastewater. The effects of adsorbent dose, initial $\mathrm{Cu}$ (II) concentration, and contact time were checked. Furthermore, adsorption isotherms and kinetic models were investigated.

\section{Materials and Methods}

\subsection{Materials}

Class F fly ash was collected from a power plant operated by CET II Holboca, located in Iasi, North-East Romania. Generally, fly ash can contain many toxic trace elements that can be easily released into the environment. Leachability tests demonstrated that the FA used in this study did not contain any toxic trace elements such as $\mathrm{Cr}$, As, Se, etc., and that it was not radioactive.

$\mathrm{Fe}_{3} \mathrm{O}_{4}$ was purchased from Alfa Aesar (Haverhill, MA, United States). All the chemical reagents were used as received.

Copper stock solution of $1000 \mathrm{mg} / \mathrm{L}$ was prepared by dissolving pentahydrate sulfate salt of copper in distilled water (Chemicals Company, Iasi, Romania). Thus, a quantity of $3.9294 \mathrm{~g}$ of $\mathrm{CuSO}_{4} 5 \mathrm{H}_{2} \mathrm{O}$ was dissolved in $1 \mathrm{~L}$ of distilled water in order to prepare $1000 \mathrm{mg} / \mathrm{L}$ of copper stock solution. The working solutions of $100-700 \mathrm{mg} / \mathrm{L} \mathrm{Cu}$ (II) were obtained by diluting an exact volume of stock solution with distilled water. The 5-(4-nitrophenylazo) salicylic acid and 2,2'-dipyridyl solution $(0.05 \%)$ were obtained by dissolving a quantity of the reagent in ethanol. The $\mathrm{pH}$ value of 3.5 necessary for metal ions complexation was obtained by using Citrate buffer solution [35]. 
Morphology of the adsorbent samples was observed with a field emission scanning electron microscope, JEOL JSM-6390 (Jeol USA Inc., Brno-Kohoutovice, Czech Republic). X-ray diffraction patterns were recorded using a Brucker AXS D8-Advance powder Xray diffractometer with CuKa radiation, $\mathrm{k}=0.1541 \mathrm{~nm}$ (Brucker, Brno, Czech Republic). Specific surface area was obtained with a Quantachrome instruments Nova 2200e model (Quantachrome Instruments, Graz, Austria). The magnetization data were acquired on a LakeShore 7410 vibrating sample magnetometer (VSM, Lake Shore Cryotronics, Inc, Westerville, $\mathrm{OH}, \mathrm{USA}$ ) in magnetic fields ranging between -20 and $20 \mathrm{kOe}$. Fourier transform infrared spectroscopy (FTIR) was performed on a Bruker Vertex 60 (Bruker Optik GmbH, Ettlingen, Germany) spectrometer.

\subsection{Adsorbent Synthesis}

The composite was obtained by milling $1 \mathrm{~g}$ of $\mathrm{Fe}_{3} \mathrm{O}_{4}$ with $9 \mathrm{~g}$ of raw fly ash (FA) in a planetary ball mill (PM-200 Retsch, Haan, Germany) for $4 \mathrm{~h}$ at $300 \mathrm{rpm}$. The grinding balls, $10 \mathrm{~mm}$ in diameter, and grinding bowls of the mill were made up of hard alloy tungsten carbide intended to operate in extreme conditions. The obtained magnetic material, noted as $\mathrm{FA} / \mathrm{Fe}_{3} \mathrm{O}_{4}$, was washed with deionized water and dried at $60{ }^{\circ} \mathrm{C}$ for $24 \mathrm{~h}$.

\subsection{Adsorption Experiments}

On the basis of previous researches on electroplating wastewater monitoring from Iasi area, the initial working concentration of synthetic solutions was established between 300$700 \mathrm{mg} / \mathrm{L}$, the results being in accordance with the literature [36]. On the other hand, AlSaydeh et al. (2017) states that copper is usually found at high concentrations in wastewater because it is the most used metal in various industrial applications, such as metal finishing, electroplating, plastics, and etching [9].

The equilibrium experiments were carried out at $\mathrm{pH} 5$ using Berzelius beakers with $0.2 \mathrm{~g}$ adsorbent dispersed in $20 \mathrm{~mL} \mathrm{Cu}$ (II) solution (initial concentrations of 100-700 mg/L).

The laboratory tests were carried out with intermittent stirring at room temperature. $\mathrm{Cu}$ (II) concentration in the supernatant was analyzed spectrophotometrically using 5-(4nitrophenylazo) salicylic acid and 2,2'-dipyridyl in ethanol medium at $520 \mathrm{~nm}$ [37] with a Shimadzu UV-2450 DR UV-vis spectrophotometer (Shimadzu, Tokyo, Japan).

The adsorption study conditions are presented in Table 1.

Table 1. Adsorption study conditions.

\begin{tabular}{|c|c|}
\hline Parameter Effect & \\
\hline $\begin{array}{c}\text { Dose of adsorbent } \rightarrow 0.2 \mathrm{~g} \text { adsorbent } / 20 \mathrm{~mL} \mathrm{Cu} \text { (II) } \\
\text { solution, } 0.4 \mathrm{~g} \text { adsorbent } / 20 \mathrm{~mL} \mathrm{Cu} \text { (II) solution, } \\
0.8 \mathrm{~g} \text { adsorbent } / 20 \mathrm{~mL} \mathrm{Cu} \text { (II) solution }\end{array}$ & $\begin{array}{l}\text { Initial } \mathrm{Cu} \text { (II) concentration: } 300 \mathrm{mg} / \mathrm{L} \text {; } \\
\qquad \mathrm{pH}=5\end{array}$ \\
\hline $\begin{array}{c}\text { Initial Cu (II) concentration } \rightarrow 100 \mathrm{mg} / \mathrm{L} \\
200 \mathrm{mg} / \mathrm{L}, 300 \mathrm{mg} / \mathrm{L}, 400 \mathrm{mg} / \mathrm{L}, 500 \mathrm{mg} / \mathrm{L} \\
600 \mathrm{mg} / \mathrm{L}, 700 \mathrm{mg} / \mathrm{L}\end{array}$ & $\begin{array}{l}\text { Dose of adsorbent }=0.2 \mathrm{~g} \\
\text { adsorbent } / 20 \mathrm{~mL} \mathrm{Cu} \text { (II) solution; } \mathrm{pH}=5\end{array}$ \\
\hline Contact time $\rightarrow 5-480 \mathrm{~min}$ & $\begin{array}{l}\text { Initial } \mathrm{Cu}(\mathrm{II}) \text { concentration: } 300 \mathrm{mg} / \mathrm{L} \text {; } \\
\text { dose of adsorbent }=0.2 \mathrm{~g} \\
\text { adsorbent } / 20 \mathrm{~mL} \mathrm{Cu} \text { (II) solution; } \mathrm{pH}=5\end{array}$ \\
\hline
\end{tabular}

The adsorption capacity, $\mathrm{q}(\mathrm{mg} / \mathrm{g})$ and the adsorption efficiency, R (\%), were calculated through Equations (1) and (2):

$$
\begin{gathered}
q_{-} e=\left(C \_0-C_{-} e\right) V / m \\
R=\left(C \_0-C \_e\right) / C \_0 \times 100
\end{gathered}
$$


where $C_{-} 0$ and $C_{-} e$ are the initial and equilibrium $\mathrm{Cu}$ (II) concentrations $(\mathrm{mg} / \mathrm{L})$, respectively, $q$ is the amount of $\mathrm{Cu}$ (II) adsorbed onto $\mathrm{FA} / \mathrm{Fe}_{3} \mathrm{O}_{4}(\mathrm{mg} / \mathrm{g}), V$ is the volume of $\mathrm{Cu}$ (II) solution (L), and $m$ is the quantity of $\mathrm{FA} / \mathrm{Fe}_{3} \mathrm{O}_{4}(\mathrm{~g})$.

The adsorption capacity at different time intervals was calculated with Equation (3):

$$
q_{-} t=\left(C_{-} 0-C_{-} t\right) V / m
$$

where $C_{-} t$ is $\mathrm{Cu}$ (II) concentration at different time intervals $(\mathrm{mg} / \mathrm{L}), q_{-} t$ is the amount of $\mathrm{Cu}$ (II) adsorbed onto $\mathrm{FA} / \mathrm{Fe}_{3} \mathrm{O}_{4}$ at time intervals $=5-480 \mathrm{~min}, \mathrm{~V}$ is the volume of solution (L), and $\mathrm{m}$ is the quantity of $\mathrm{FA} / \mathrm{Fe}_{3} \mathrm{O}_{4}(\mathrm{~g})$.

\section{Results}

3.1. Characterization of $\mathrm{FA} / \mathrm{Fe}_{3} \mathrm{O}_{4}$ Adsorbent

$\mathrm{FA} / \mathrm{Fe}_{3} \mathrm{O}_{4}$ adsorbent was characterized through SEM, EDAX, XRD, FTIR, and VSM.

\subsubsection{SEM Analysis}

The morphology shown in Figure 1 demonstrated that $\mathrm{FA} / \mathrm{Fe}_{3} \mathrm{O}_{4}$ is composed by spherical particles, with large size distribution. Together with regular spherical particles, there were smaller irregular fly ash particles, which were likely derived from the high content of iron oxide and unburned carbon, as well as irregularly shaped amorphous particles. The sizes of the particles observed in Figure 1a are less than $5 \mu \mathrm{m}$, and the majority of the particles consisting in solid spheres ranged in size from 1 to $5 \mu \mathrm{m}$ [38].

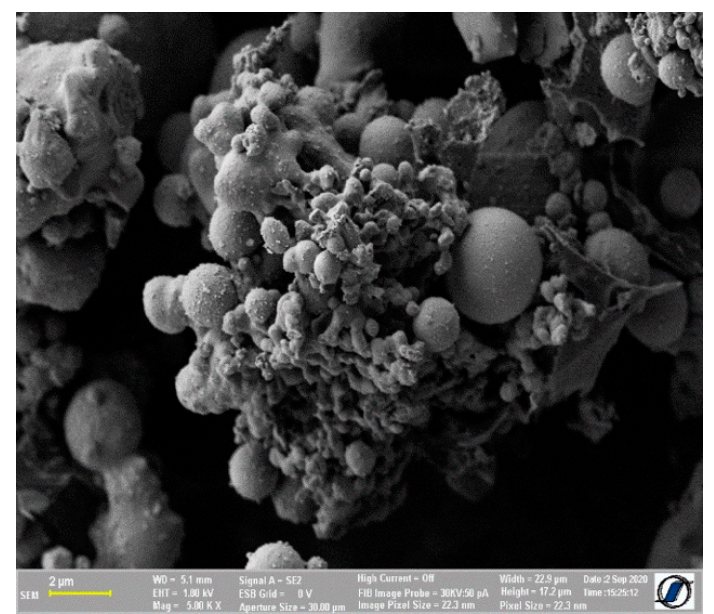

(a) FA

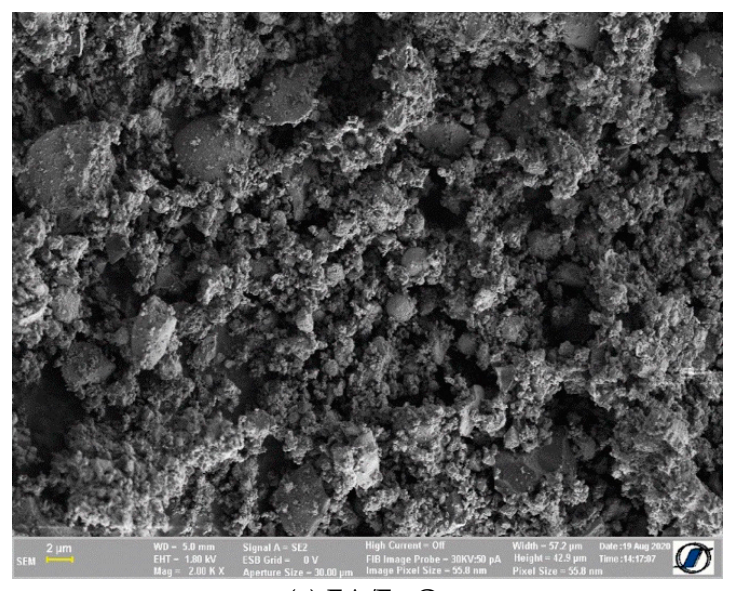

(c) $\mathrm{FA} / \mathrm{Fe}_{3} \mathrm{O}_{4}$

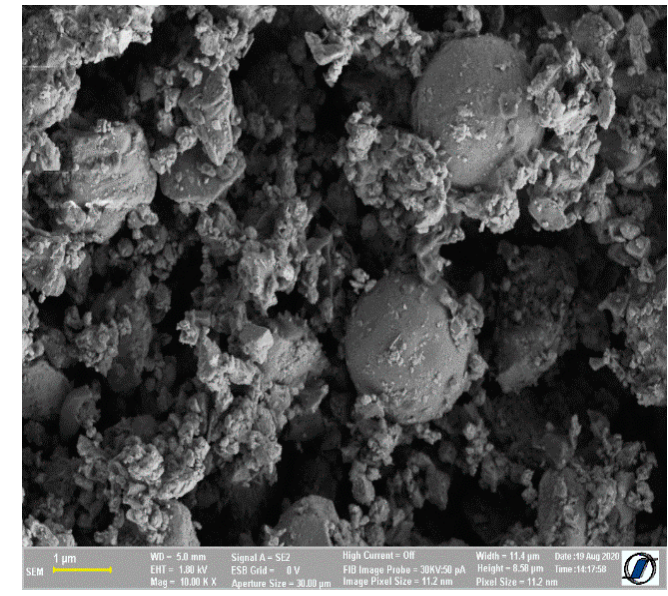

(b) $\mathrm{FA} / \mathrm{Fe}_{3} \mathrm{O}_{4}$

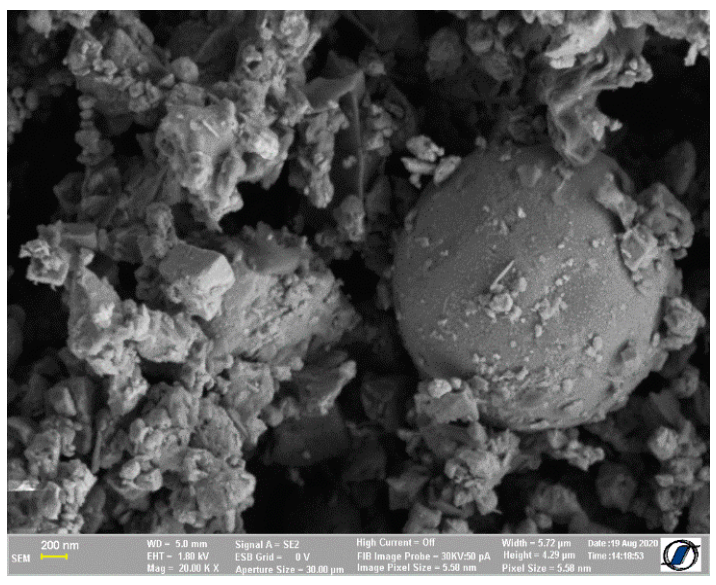

(d) $\mathrm{FA} / \mathrm{Fe}_{3} \mathrm{O}_{4}$

Figure 1. SEM image of the prepared composite. 
By milling, the agglomerated particles of FA were destroyed, and the magnetite added was uniformly distributed (Figure 1c). The SEM images show a uniform distribution of both small particle and magnetite within the composite. The SEM of the $\mathrm{FA} / \mathrm{Fe}_{3} \mathrm{O}_{4}$ demonstrated that the fly ash was well crushed, and that the shapes of the particles became more uniform. The sizes were significantly reduced to about $600 \mathrm{~nm}$, indicating the breakdown of the original spherical-shaped fly ash.

\subsubsection{EDAX Analysis}

The chemical composition established through EDAX analysis is presented in Figure 2.
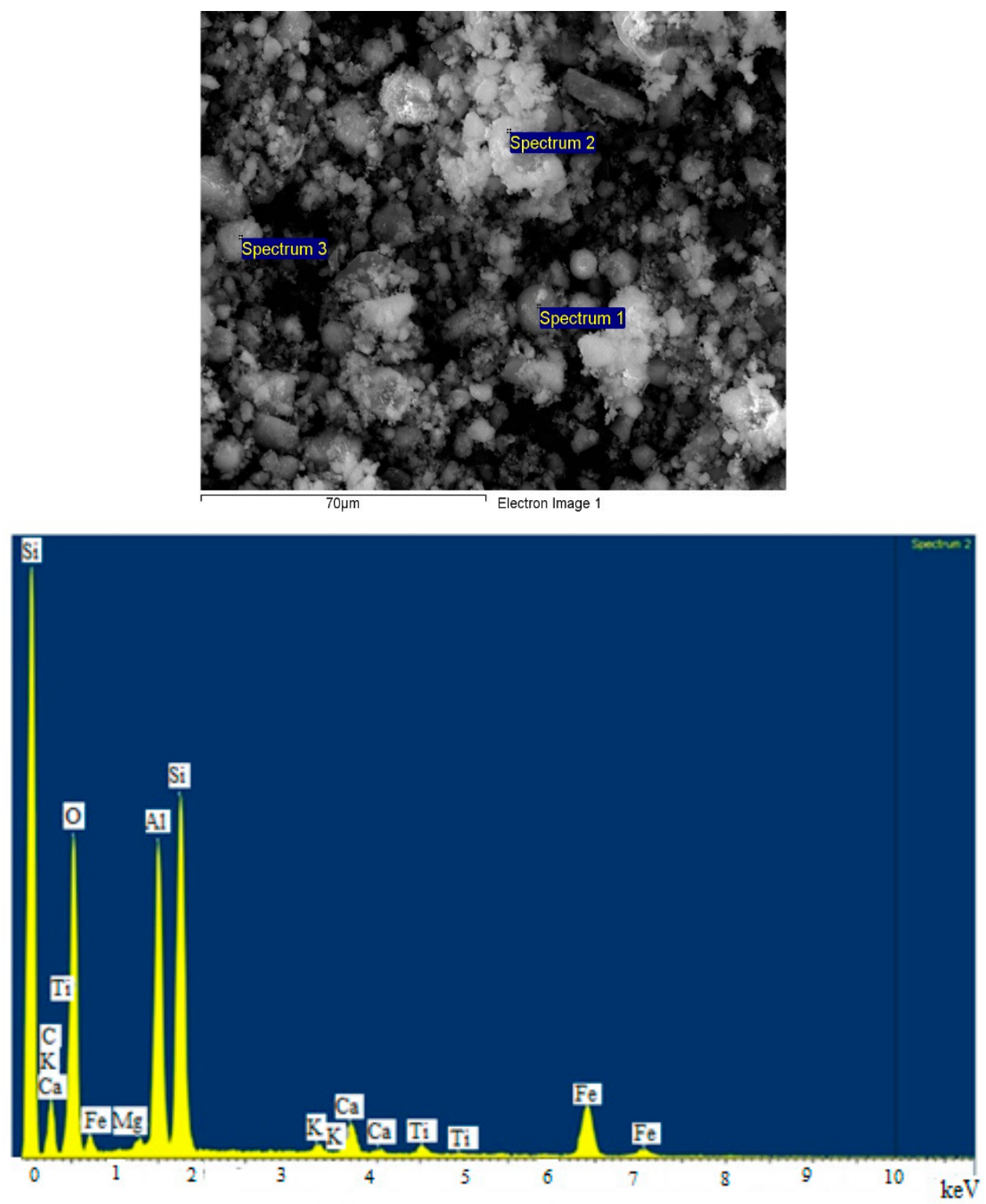

Figure 2. $\mathrm{EDAX}$ spectrum of $\mathrm{FA} / \mathrm{Fe}_{3} \mathrm{O}_{4}$.

The comparison between raw material and synthesized material is presented in Table 2.

As determined by EDS, the predominant elements in the adsorbent samples in various compositions were oxygen, unburned carbon, silicon, aluminum, iron, and calcium [39]. Minor amounts of magnesium, titanium, sodium, and potassium were found in analyzed samples. By comparing the data obtained for $\mathrm{Fe}$ in the case of $\mathrm{FA} / \mathrm{Fe}_{3} \mathrm{O}_{4}(7.74 \%)$ vs. FA $(2.05 \%)$, it can be highlighted that the synthesis took place successfully. The mapping 
diagram demonstrated that the magnetite was uniformly distributed; consequently, milling time $(4 \mathrm{~h})$ led to a proper homogeneity.

Table 2. Elemental analysis of $\mathrm{FA}$ and $\mathrm{FA} / \mathrm{Fe}_{3} \mathrm{O}_{4}$, mass \%.

\begin{tabular}{ccc}
\hline Element & FA & $\mathbf{F A} / \mathbf{F e}_{3} \mathbf{O}_{\mathbf{4}}$ \\
\hline $\mathrm{C}$ & 18.27 & 18.25 \\
$\mathrm{O}$ & 45.82 & 46.72 \\
$\mathrm{Si}$ & 18.81 & 13.95 \\
$\mathrm{Al}$ & 11.09 & 10.22 \\
$\mathrm{Ca}$ & 1.75 & 1.7 \\
$\mathrm{Fe}$ & 2.05 & 7.74 \\
$\mathrm{~K}$ & 0.79 & 0.41 \\
$\mathrm{Mg}$ & 0.60 & 0.34 \\
$\mathrm{Ti}$ & 0.74 & 0.67 \\
\hline
\end{tabular}

\subsubsection{FTIR Analysis}

The results of the FTIR analysis are illustrated in Figure 3. The FTIR analysis was realized to estimate the presence of the functional groups on the solid surface, the strength of the bonds, and the interactions between the surface functional groups and the adsorbed $\mathrm{Cu}$ (II).

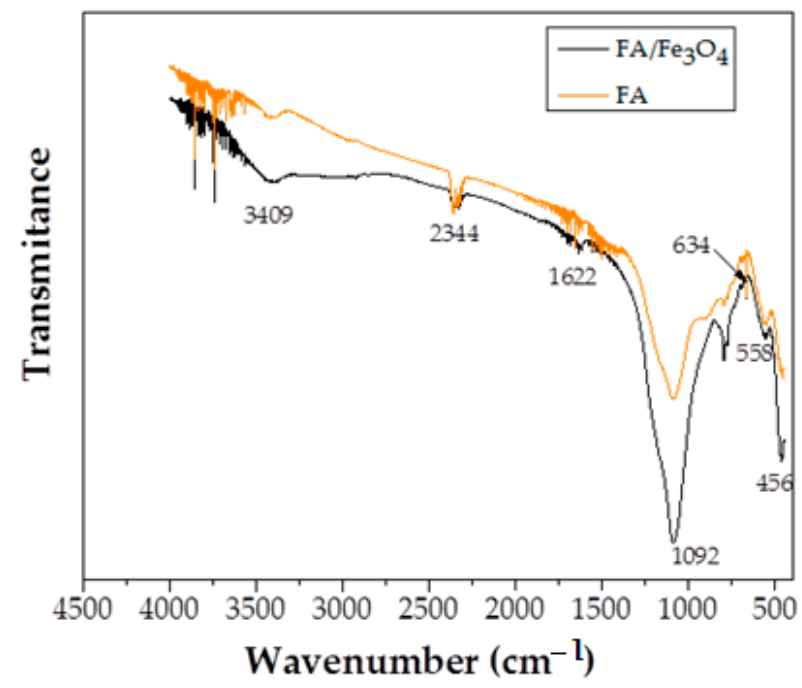

Figure 3. FTIR spectra of FA and FA/ $\mathrm{Fe}_{3} \mathrm{O}_{4}$.

The band, observed at the $\sim 530$ spectrum of $\mathrm{FA} / \mathrm{Fe}_{3} \mathrm{O}_{4}$, corresponds to the $\mathrm{Fe}-\mathrm{O} / \mathrm{Fe}$ $\mathrm{OH}$ vibration of magnetite phase. The significant peak at $634 \mathrm{~cm}^{-1}$ is characteristic to magnetite. Apart from these, no significant change was observed between the FTIR spectra of $\mathrm{FA}$ and $\mathrm{FA} / \mathrm{Fe}_{3} \mathrm{O}_{4}$.

The peak at $456 \mathrm{~cm}^{-1}$ was assigned to $\mathrm{Si}-\mathrm{O} / \mathrm{Al}-\mathrm{O}$ in plane bending vibration and $\mathrm{Si}-\mathrm{O}$ bending vibration, and the peak at $558 \mathrm{~cm}^{-1}$ was attributed to the Si-O vibration [40].

On the other hand, the peak at $1092 \mathrm{~cm}^{-1}$ was assigned to the asymmetric stretching of $\mathrm{Si}-\mathrm{O}-\mathrm{Si}$. The very small peaks corresponded to $\mathrm{H}-\mathrm{O}$ vibration (the samples were dried before analysis).

Taking into consideration that the only compositional difference between samples was the content of $\mathrm{Fe}_{3} \mathrm{O}_{4}$, no transformations were obvious in the structure of the material. The only difference in Figure 3 emerges from the higher $\mathrm{Fe}_{3} \mathrm{O}_{4}$ content, leading to an increase in the intensity of the spectrum associated with $\mathrm{FA} / \mathrm{Fe}_{3} \mathrm{O}_{4}$. 


\subsubsection{XRD Analysis}

The XRD analysis was performed in order to receive information about the mineralogical composition of the synthesized adsorbent, the results being presented in Figure 4. As it can be seen from the Figure 4, FA/ $\mathrm{Fe}_{3} \mathrm{O}_{4}$ has the crystal phases of mullite (M) and quartz $(\mathrm{Q})$. According to the X-ray pattern, the hematite (He) was found in the synthesized material. Also, from Figure 4 it can be noted that the XRD curve of $\mathrm{FA} / \mathrm{Fe}_{3} \mathrm{O}_{4}$ has an amorphous structure [41] due to the formation of broad bands, and a crystalline phase within a wide scanning interval of $10-70^{\circ}$. Besides these peaks originating from the ash, the peaks at 2 theta (degrees) equaling $18.35^{\circ}, 30.35^{\circ}, 35.8^{\circ}, 43.06^{\circ}, 57.12^{\circ}$, and $62.73^{\circ}$ correspond to $\mathrm{Fe}_{3} \mathrm{O}_{4}$. Additionally, an important variation in the peak intensity can be noticed from Figure 4 . The comparison between the XRD diffraction patterns indicated the introduction of $\mathrm{Fe}_{3} \mathrm{O}_{4}$ on the FA structure.

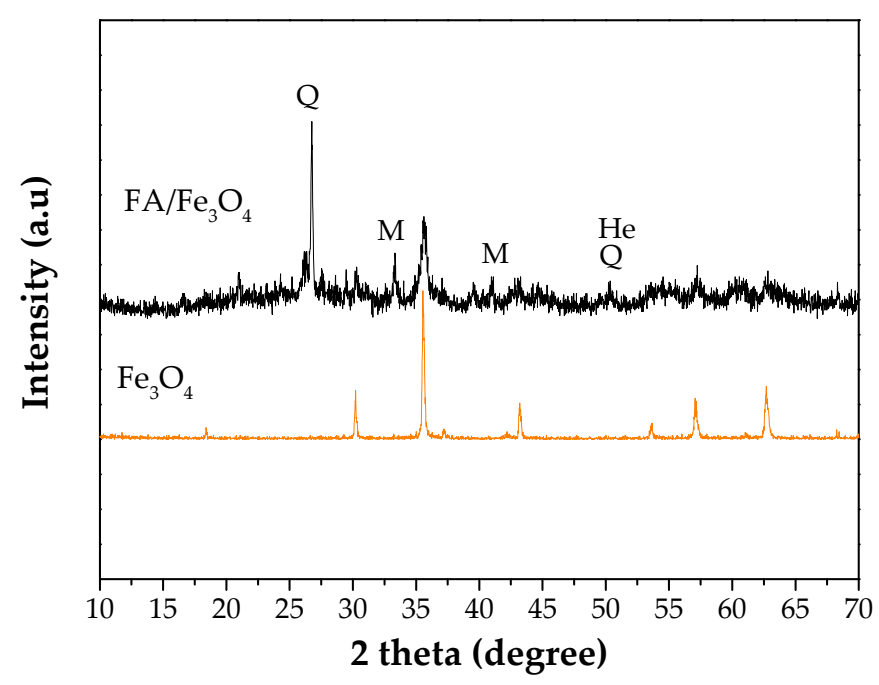

Figure 4. X-ray diffraction patterns of $\mathrm{Fe}_{3} \mathrm{O}_{4}$ and $\mathrm{FA} / \mathrm{Fe}_{3} \mathrm{O}_{4}$.

\subsubsection{BET Analysis}

The $\mathrm{N}_{2}$ adsorption-desorption isotherm for $\mathrm{FA} / \mathrm{Fe}_{3} \mathrm{O}_{4}$ is shown in Figure 5 .

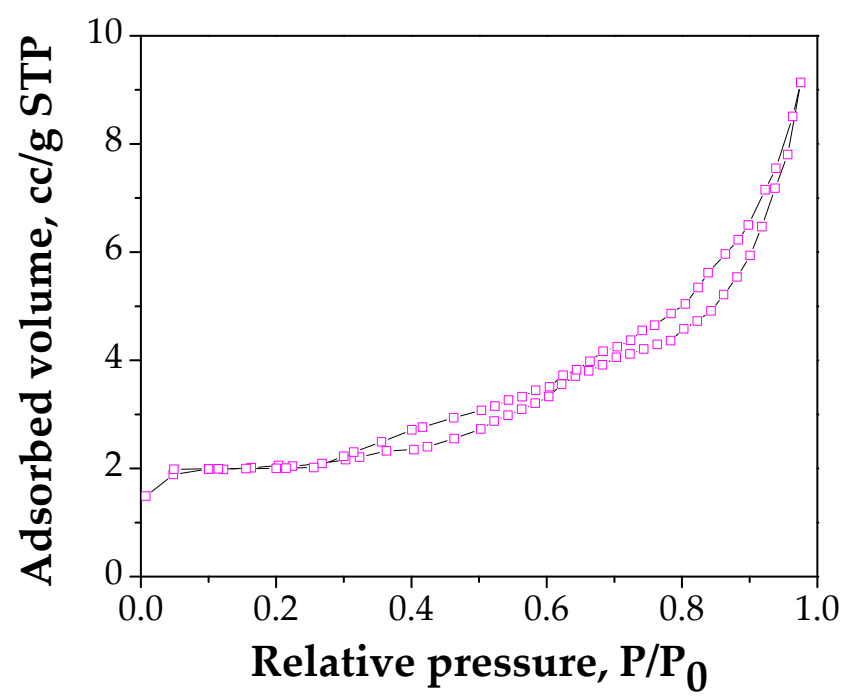

Figure 5. Nitrogen adsorption isotherm at $77 \mathrm{~K}$ on $\mathrm{FA} / \mathrm{Fe}_{3} \mathrm{O}_{4}$.

The BET data shows that the specific surface area of $\mathrm{FA} / \mathrm{Fe}_{3} \mathrm{O}_{4}$ is $6.153 \mathrm{~m}^{2} / \mathrm{g}$, while the total pore volume is $0.0121 \mathrm{~cm}^{3} / \mathrm{g}$. FA used in this study has the BET area of $4.03 \mathrm{~m}^{2} / \mathrm{g}$ and the total pore volume $0.009 \mathrm{~cm}^{3} / \mathrm{g}$. The results show that the surface area of $\mathrm{FA} / \mathrm{Fe}_{3} \mathrm{O}_{4}$ 
is 1.5 times higher compared with FA, which can be attributed to the interfacial interaction between FA and magnetite. Furthermore, $\mathrm{FA} / \mathrm{Fe}_{3} \mathrm{O}_{4}$ is a mesoporous material, in accordance with the classification of IUPAC (International Union of Pure and Applied Chemistry, USA) [42], with an average pore volume of $7.85 \mathrm{~nm}$.

\subsubsection{VSM Analysis}

The specific saturation magnetization (ssM) of the FA increased by more than $300 \%$ after mixing with $\mathrm{Fe}_{3} \mathrm{O}_{4}$ (Figure 6). Taking into account the mass ratio of 9:1 between FA and magnetite, a value of $88.6 \mathrm{emu} / \mathrm{g}$ can be calculated for the ssM of magnetite dispersed in the FA. This is consistent with the ssM obtained for magnetite, i.e., 87.1 (Figure 6), showing a negligible influence of the ball milling process on the magnetic properties.

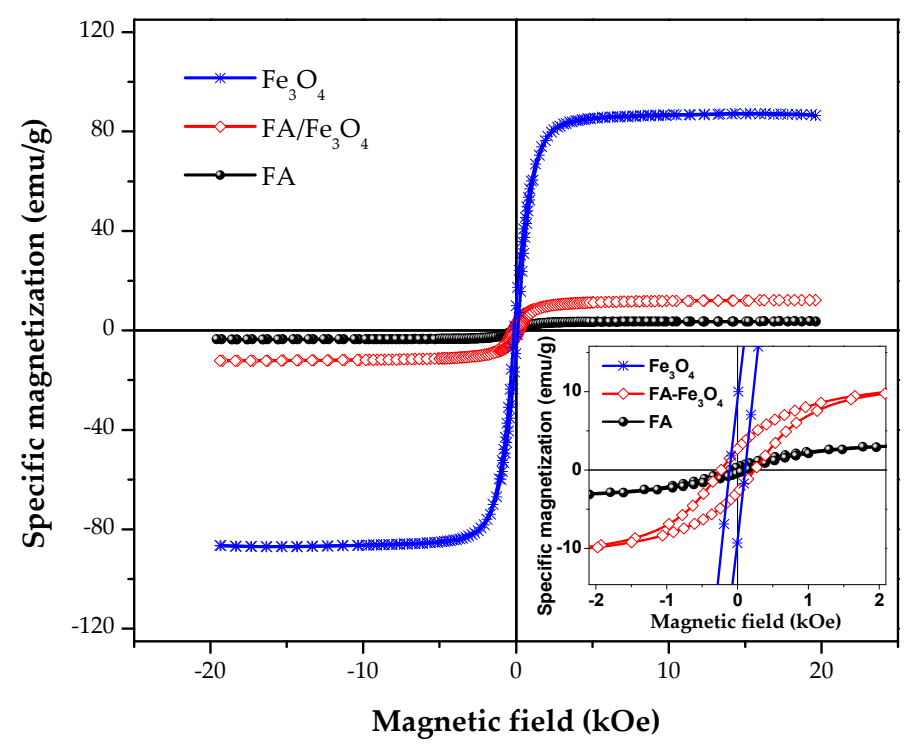

Figure 6. Magnetization hysteresis loop of the $\mathrm{FA} / \mathrm{Fe}_{3} \mathrm{O}_{4}$ vs. FA.

From Figure 6, it can be observed that there are significant differences in the coercive field $(\mathrm{Hc})$ and squareness values $(\mathrm{Mr} / \mathrm{Ms})$ of the samples. FA shows lower values for $\mathrm{Hc}$ and $\mathrm{Mr} / \mathrm{Ms}$ ratio, being therefore less susceptible to agglomeration than $\mathrm{FA}^{-}-\mathrm{Fe}_{3} \mathrm{O}_{4}$ particles. However, FA would need much more intense magnetic fields to be separated, after completing the water cleaning process, compared with $\mathrm{FA} / \mathrm{Fe}_{3} \mathrm{O}_{4}$ particles.

\subsection{Effect of Adsorption Parameters}

\subsubsection{Effect of FA/ $\mathrm{Fe}_{3} \mathrm{O}_{4}$ Dose}

Generally, the adsorbent dose has a high impact on the adsorption capacity. To establish the effect of an $\mathrm{FA} / \mathrm{Fe}_{3} \mathrm{O}_{4}$ dose on $\mathrm{Cu}$ (II) adsorption, a series of adsorption experiments were carried out using three adsorbent doses $(0.2 \mathrm{~g} / 20 \mathrm{~mL}, 0.4 \mathrm{~g} / 20 \mathrm{~mL}$, and $0.8 \mathrm{~g} / 20 \mathrm{~mL})$. The other parameters involved were an initial $\mathrm{Cu}$ (II) concentration of $300 \mathrm{mg} / \mathrm{L}$, a pH of 5 , a contact time of $24 \mathrm{~h}$, and a temperature of $26^{\circ} \mathrm{C}$. It can be observed that with the increase in the $\mathrm{FA} / \mathrm{Fe}_{3} \mathrm{O}_{4}$ dose, for a constant volume of solution and for the same initial concentration of $\mathrm{Cu}$ (II) ion, the adsorption capacity decreases. As shown in Figure 7, the best result was obtained using $10 \mathrm{~g} / \mathrm{L}$ of $\mathrm{FA} / \mathrm{Fe}_{3} \mathrm{O}_{4}$, with $13.48 \mathrm{mg} / \mathrm{g}$ of the $\mathrm{Cu}$ (II) adsorbed.

Also, FA presents the same trend. The adsorption capacity decreases with an increase in the adsorbent dose. The rationale behind this behavior might be related to the aggregation of the magnetic particles once the dose is increased, which consequently leads to the decrease in adsorption capacity. This fact was observed when the fly ash was treated with $\mathrm{NaOH}$ and $\mathrm{H}_{2} \mathrm{SO}_{4}[15,26]$. Additionally, other researchers have obtained similar results [12,24]. 


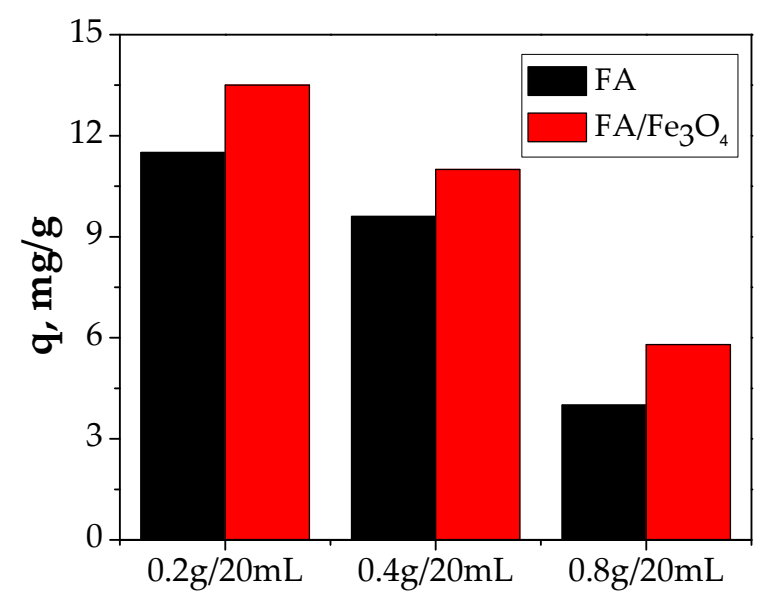

\section{Adsorbent dose}

Figure 7. The effect of $\mathrm{FA} / \mathrm{Fe}_{3} \mathrm{O}_{4}$ dose (experimental conditions-initial $\mathrm{pH}=5.0$; initial metal concentration $=300 \mathrm{mg} / \mathrm{L}$; contact time $=24 \mathrm{~h}$; temperature $=26^{\circ} \mathrm{C}$ ).

\subsubsection{Effect of Initial Concentration}

The results regarding the influence of the concentration of FA and $\mathrm{FA} / \mathrm{Fe}_{3} \mathrm{O}_{4}$ in the range of $100-700 \mathrm{mg} / \mathrm{L}$ are presented in Figure 8.

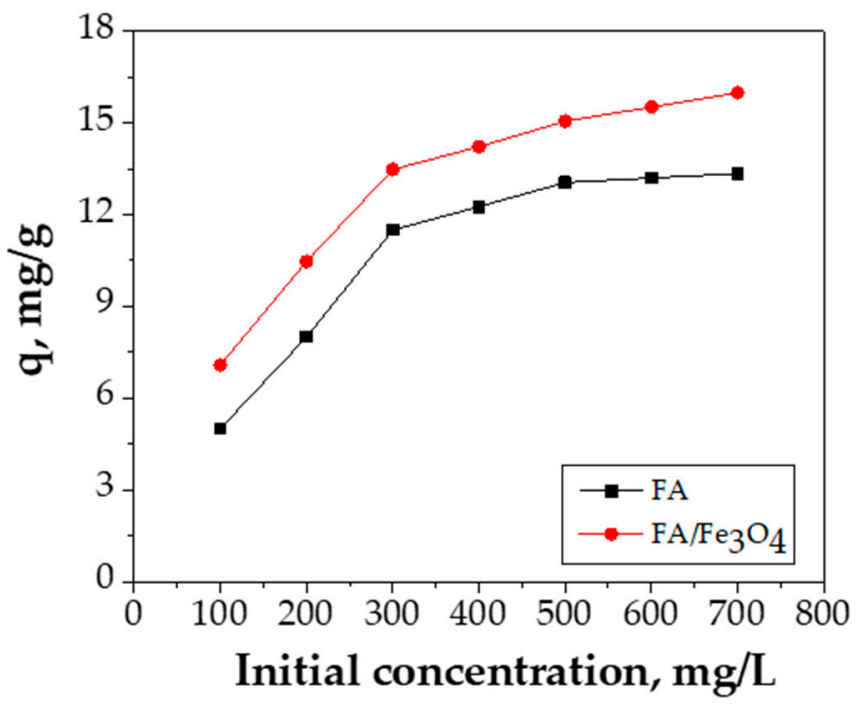

(a)

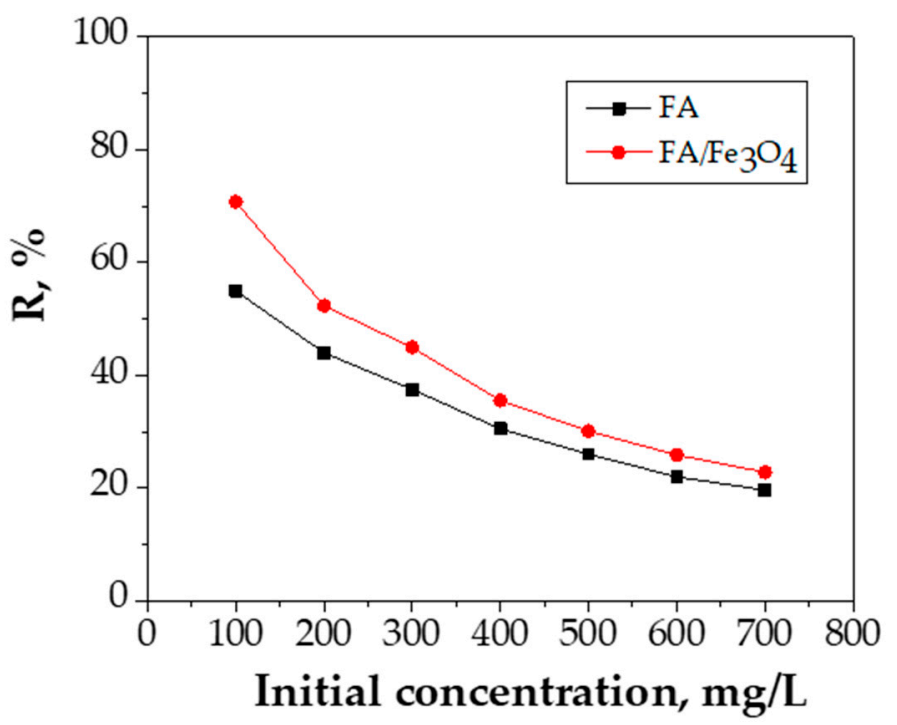

(b)

Figure 8. The effect of initial concentration on: (a) adsorption capacity, (b) adsorption efficiency (experimental conditionsinitial $\mathrm{pH}=5.0$; adsorbent dosage $=0.2 \mathrm{~g}$ adsorbent $/ 20 \mathrm{~mL} \mathrm{Cu}$ (II) solution; contact time $=24 \mathrm{~h}$; temperature $=26^{\circ} \mathrm{C}$ ).

The following observations could be drawn from Figure 8: the lower $\mathrm{Cu}$ (II) concentrations (100 mg/L and $200 \mathrm{mg} / \mathrm{L}$ ) show lower adsorption capacities; the initial Cu (II) concentration of 300 and $400 \mathrm{mg} / \mathrm{L}$ mark out the adsorption capacities of $11.9 \mathrm{mg} / \mathrm{g}$ and $12.26 \mathrm{mg} / \mathrm{g}$ for FA, respectively, whereas $13.48 \mathrm{mg} / \mathrm{g}$ and $14.22 \mathrm{mg} / \mathrm{g}$ mark out the adsorption capacities for $\mathrm{FA} / \mathrm{Fe}_{3} \mathrm{O}_{4}$; the increase in concentration toward $500 \mathrm{mg} / \mathrm{L}$ led to an adsorption capacity of $13.05 \mathrm{mg} / \mathrm{g}$ for FA and $15.05 \mathrm{mg} / \mathrm{g}$ for FA/ $/ \mathrm{Fe}_{3} \mathrm{O}_{4}$; at an initial $\mathrm{Cu}$ (II) concentration of 500,600 , and $700 \mathrm{mg} / \mathrm{L}$, the adsorption capacity was approximately similar, although the removal efficiency decreased.

The adsorption efficiency shows a decreasing trend with the initial concentration of the $\mathrm{Cu}$ (II) ions from 100 to $700 \mathrm{mg} / \mathrm{L}$. The adsorption sites are rapidly occupied at low $\mathrm{Cu}$ (II) concentration. As the initial concentration of $\mathrm{Cu}$ (II) increased, the majority of the 
accessible adsorption sites were no longer available, leading to a decrease of the removal efficiency.

\subsubsection{Effect of Contact Time}

In order to establish the contact time necessary to reach equilibrium, different contact times (5-480 $\mathrm{min}$ ) were used. The effect of contact time on $\mathrm{Cu}$ (II) adsorption capacity using $\mathrm{FA}$ and $\mathrm{FA} / \mathrm{Fe}_{3} \mathrm{O}_{4}$ adsorbents is presented in Figure 9.

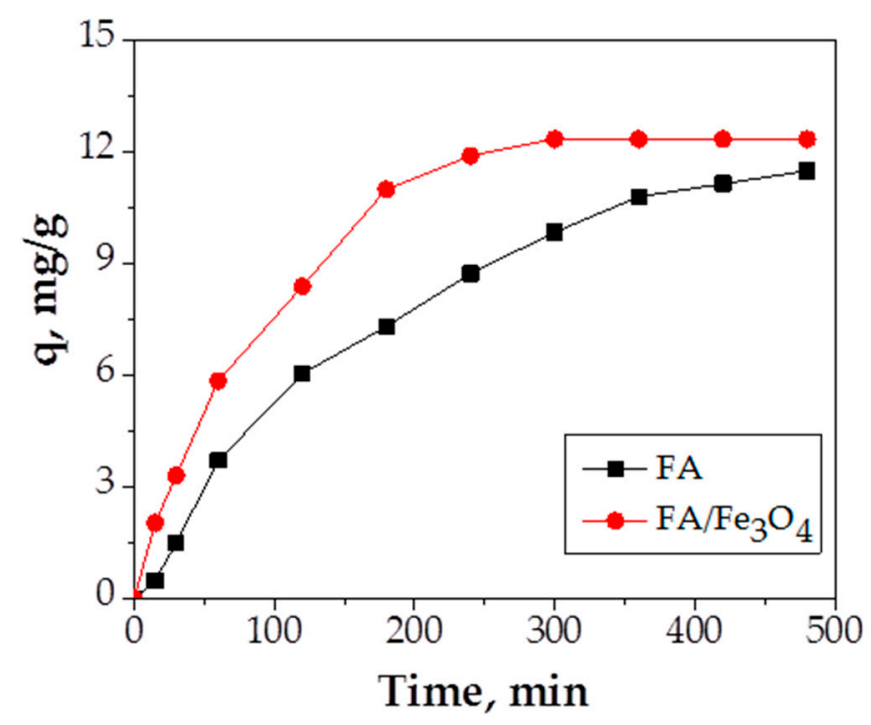

Figure 9. The effect of contact time (experimental conditions-initial $\mathrm{pH}=5.0$; adsorbent dosage $=0.2 \mathrm{~g}$ adsorbent $/ 20 \mathrm{~mL} \mathrm{Cu}$ (II) solution; initial metal concentration $=300 \mathrm{mg} / \mathrm{L}$; temperature $=26^{\circ} \mathrm{C}$ ).

According to the obtained results, Figure 9 clearly proves that the contact time has an influence on $\mathrm{Cu}$ (II) adsorption capacity; by increasing contact time, the adsorption capacity increases. The results show that a maximum adsorption capacity of $12.21 \mathrm{mg} / \mathrm{g}$ is obtained in $4 \mathrm{~h}$ of contact in the case of $\mathrm{Fe}_{3} \mathrm{O}_{4}$, as opposed to $11.9 \mathrm{mg} / \mathrm{g}$ after $6 \mathrm{~h}$ in the case of FA. The superiority of FA/ $\mathrm{Fe}_{2} \mathrm{O}_{3}$ material was observed between 180 and $300 \mathrm{~min}$ of contact time. The reduction of contact time in the process of wastewater treatment saves energy and time. This fact shows that the insertion of $\mathrm{Fe}_{3} \mathrm{O}_{4}$ in the structure of raw fly ash represents a worthy advantage added to the induced magnetization.

\subsection{Adsorption Isotherms}

Adsorption isotherms and kinetic study offer valuable information regarding the adsorption process and specific properties of the adsorbent surface which are necessary for designing the adsorption systems.

The amount of $\mathrm{Cu}$ (II) adsorbed on the $\mathrm{FA} / \mathrm{Fe}_{3} \mathrm{O}_{4}$ and the concentration of $\mathrm{Cu}$ (II) at equilibrium was explained using four common adsorption isotherms: Langmuir (four types of its linearization), Freundlich, Temkin, and Harkins-Jura (Figure 10 and Table 3). The related literature offers a complete description regarding the hypothesis, and the equation characteristic for each type of isotherm and kinetic model [20,43-46].

The correlated parameters of both equations are shown in Table 3. It should be mentioned that the value of experimentally obtained $\mathrm{q}_{\max }$ is $15.991 \mathrm{mg} / \mathrm{g}$.

In the case of $\mathrm{FA} / \mathrm{Fe}_{3} \mathrm{O}_{4}$, by comparing the four isotherm models, it is noticed that the Langmuir equation shows a higher value of correlation coefficient, $\mathrm{R}^{2}$, compared with the Freundlich, Temkin, and Harkins-Jura isotherm models. 

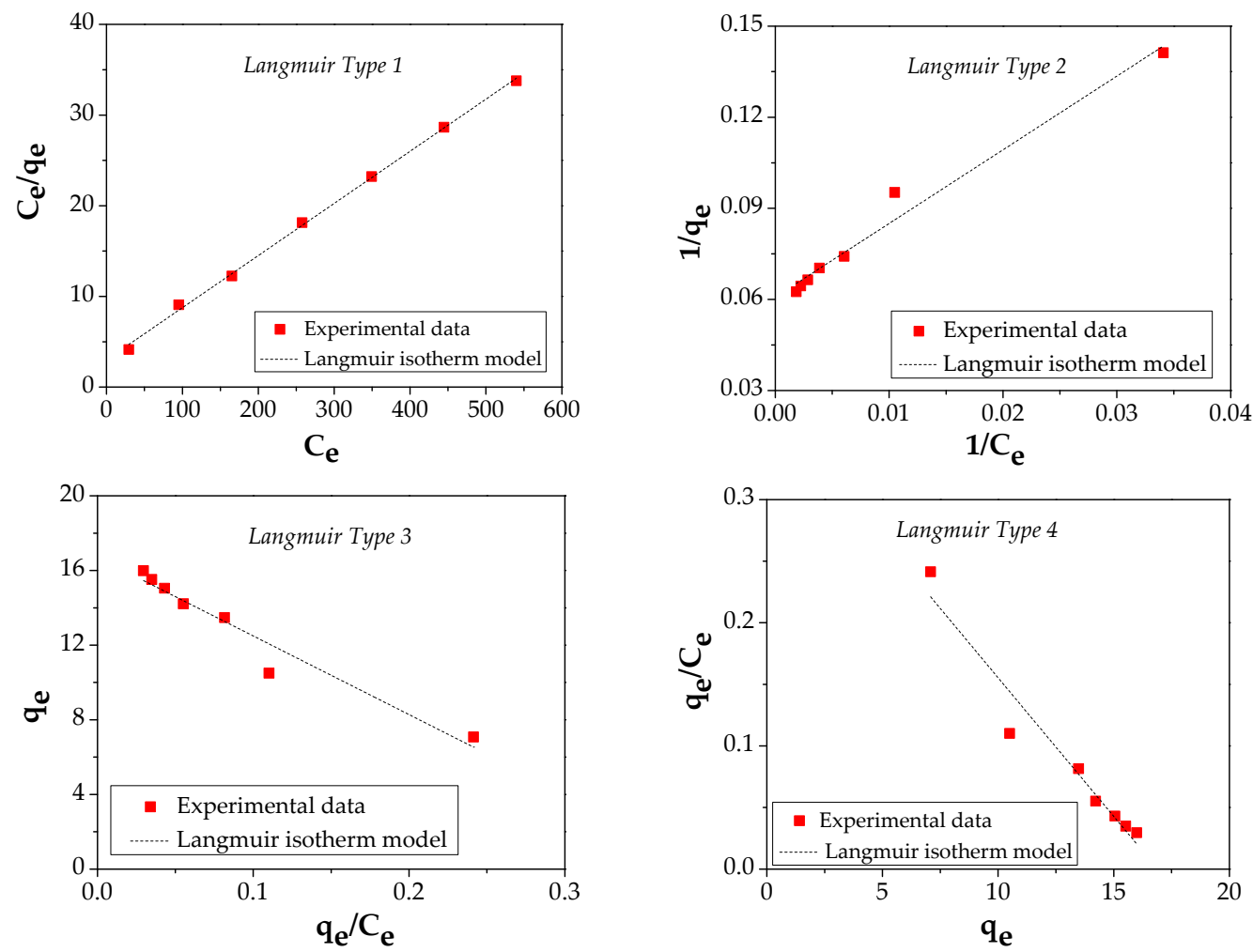

(a)

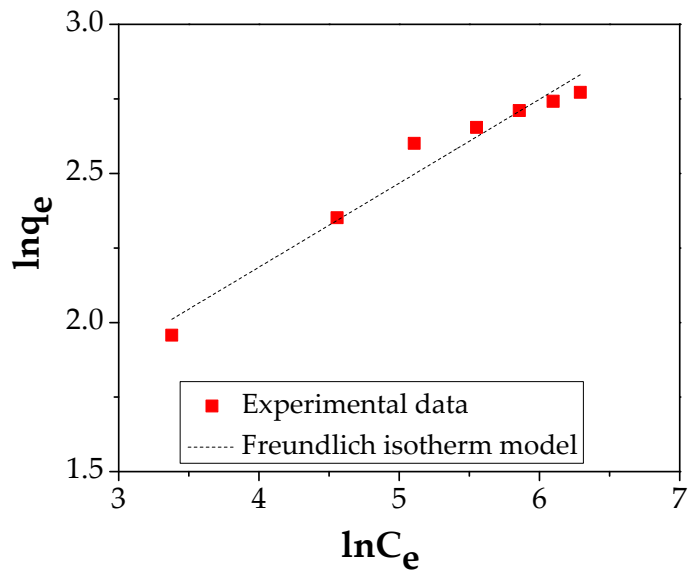

(b)

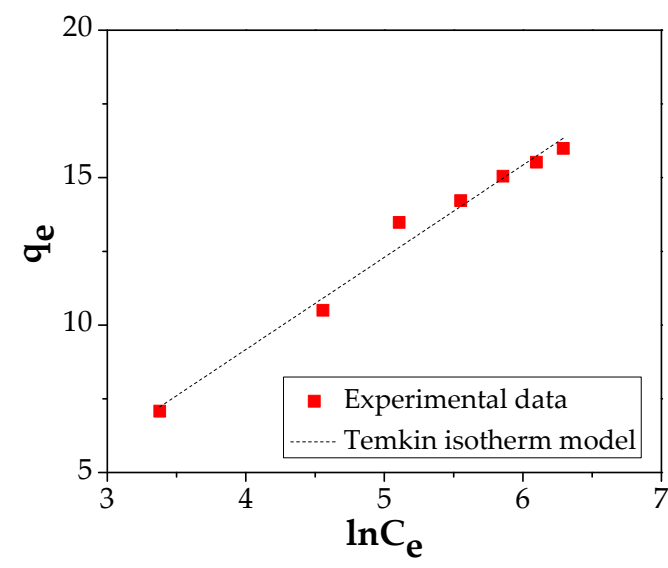

(c)

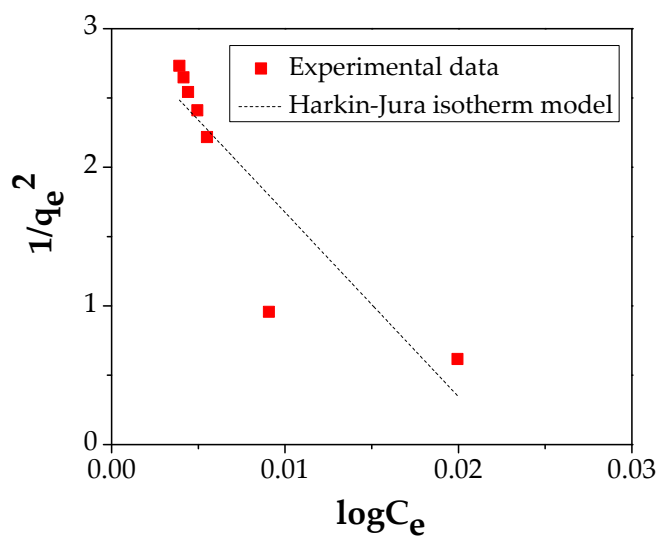

(d)

Figure 10. (a) Langmuir isotherm plot; (b) Freundlich isotherm plot; (c) Temkin isotherm plot; (d) Harkins-Jura isotherm plot. 
Table 3. The correlated parameters of isotherms of $\mathrm{Cu}$ (II) adsorption onto $\mathrm{FA} / \mathrm{Fe}_{3} \mathrm{O}_{4}$.

\begin{tabular}{|c|c|c|}
\hline Model & Parameter & Value \\
\hline \multirow{3}{*}{ Langmuir type 1} & q_max & 17.39 \\
\hline & $K \_L$ & 0.0191 \\
\hline & $\overline{R^{2}}$ & 0.9987 \\
\hline \multirow{3}{*}{ Langmuir type 2} & q_max & 16.44 \\
\hline & $K \_L$ & 0.025 \\
\hline & $\mathrm{R}^{2}$ & 0.9792 \\
\hline \multirow{3}{*}{ Langmuir type 3} & q_max & 16.71 \\
\hline & $K \_L$ & 0.0237 \\
\hline & $R^{2}$ & 0.9487 \\
\hline \multirow{3}{*}{ Langmuir type 4} & q_max & 16.91 \\
\hline & $K \_L$ & 0.0225 \\
\hline & $\mathrm{R}^{2}$ & 0.9487 \\
\hline \multirow{3}{*}{ Freundlich } & $K \_F$ & 2.88 \\
\hline & $1 / \mathrm{n}$ & 0.2816 \\
\hline & $\mathrm{R}^{2}$ & 0.9625 \\
\hline \multirow{4}{*}{ Temkin } & B & 3.1282 \\
\hline & $\mathrm{b}$ & 0.792 \\
\hline & $\mathrm{A}_{\mathrm{T}}$ & 3.25 \\
\hline & $\mathrm{R}^{2}$ & 0.9821 \\
\hline \multirow{3}{*}{ Harkins-Jura } & $\mathrm{A}_{\mathrm{HJ}}$ & 0.0075 \\
\hline & $\mathrm{B}_{\mathrm{HJ}}$ & 0.0226 \\
\hline & $\mathrm{R}^{2}$ & 0.9002 \\
\hline
\end{tabular}

where: $q_{\_} \max$ is the maximum adsorption capacity $(\mathrm{mg} / \mathrm{g}) ; K_{-} L$ is Langmuir constant $(\mathrm{L} / \mathrm{g}) ; K_{-} F$ is the Freundlich constant; $1 / \mathrm{n}$ is the heterogeneity factor; $\mathrm{A}_{\mathrm{T}}$ is Temkin isotherm equilibrium binding constant $(\mathrm{L} / \mathrm{g})$; $\mathrm{b}_{\mathrm{T}}$ is Temkin isotherm constant; $\mathrm{B}$ is the constant related to heat of adsorption $(\mathrm{J} / \mathrm{mol})$; $\mathrm{A}_{\mathrm{HJ}}$ and $\mathrm{B}_{\mathrm{HJ}}$ are Harkins-Jura constants. The bold of 0.0987: to highlight the high value of $\mathrm{R}^{2}$.

The four different linear Langmuir equations show that the adsorption capacities obtained are $17.39 \mathrm{mg} / \mathrm{g}$ for Type I, $16.44 \mathrm{mg} / \mathrm{g}$ for Type II, $16.71 \mathrm{mg} / \mathrm{g}$ for Type III, and $16.91 \mathrm{mg} / \mathrm{g}$ for Type IV, while the values of the $K \_L$ are $0.0191,0.025,0.0237$, and $0.0225 \mathrm{~L} / \mathrm{g}$, respectively. The value of the correlation coefficient, $\mathrm{R}^{2}$, of 0.9991 , shows that Langmuir equation type 1 is able to describe the $\mathrm{Cu}$ (II) adsorption process onto $\mathrm{FA} / \mathrm{Fe}_{3} \mathrm{O}_{4}$. Consequently, it can be concluded that the adsorption process is a monolayer uniform adsorption [47].

The nature of the adsorption process (favorable/unfavorable) is established according with the dimensionless separation factor, $\mathrm{R}_{\mathrm{L}}$ :

$$
\mathrm{R} \_\mathrm{L}=1 /\left(1+K \_L \times C \_0\right)
$$

where $K \_L$ is Langmuir constant and $C \_0$ is the initial $\mathrm{Cu}$ (II) concentration in the range $100-700 \mathrm{mg} / \mathrm{L}$.

The fitting curve of $R_{\mathrm{L}}$ vs. $\mathrm{C}_{0}$ is presented in Figure 11.

The value achieved between 0 and 1 demonstrates that the adsorption process of $\mathrm{Cu}$ (II) onto $\mathrm{FA} / \mathrm{Fe}_{3} \mathrm{O}_{4}$ is a favorable process [48].

The results obtained for two kinetic models: pseudo-first-order and pseudo-secondorder are presented in Figure 12 and Table 4.

In the case of the pseudo-first-order equation, the value of correlation coefficient, $\mathrm{R}^{2}$, was 0.9871 with a reaction rate constant, $\mathrm{k}_{1}$, of $0.0124(\mathrm{~L} / \mathrm{min})$. The $\mathrm{k}_{2}$ constant of the pseudo-second-order equation and $\mathrm{R}^{2}$ for $\mathrm{Cu}$ (II) adsorption onto $\mathrm{FA} / \mathrm{Fe}_{3} \mathrm{O}_{4}$ were $0.00056 \mathrm{~g} / \mathrm{mg} \mathrm{min}$ and 0.993 , respectively. 


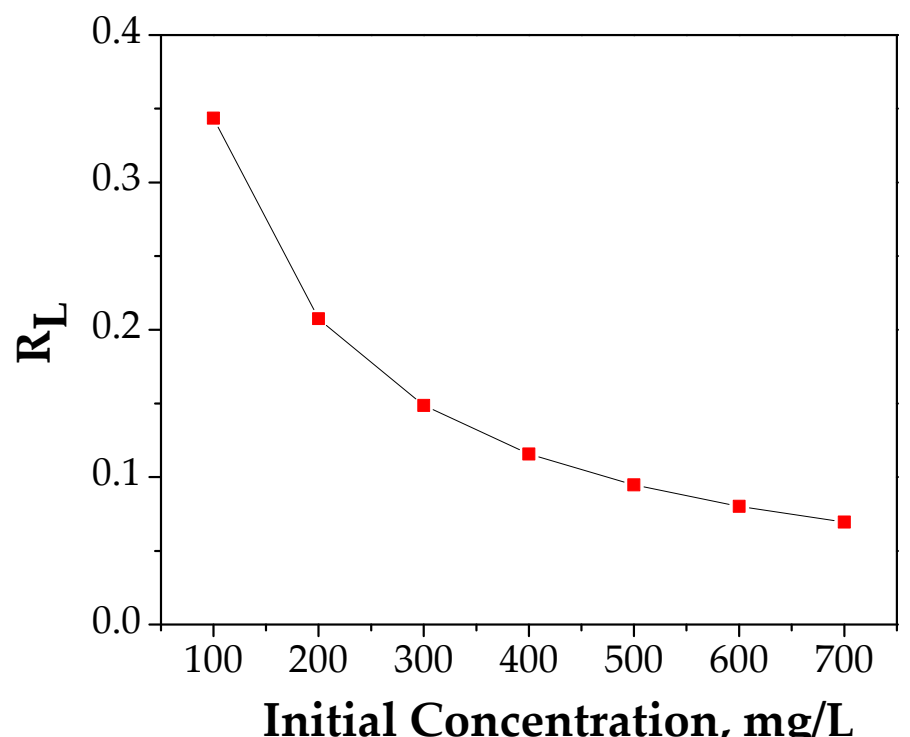

Figure 11. Plot of separation factor vs. initial $\mathrm{Cu}$ (II) concentration.

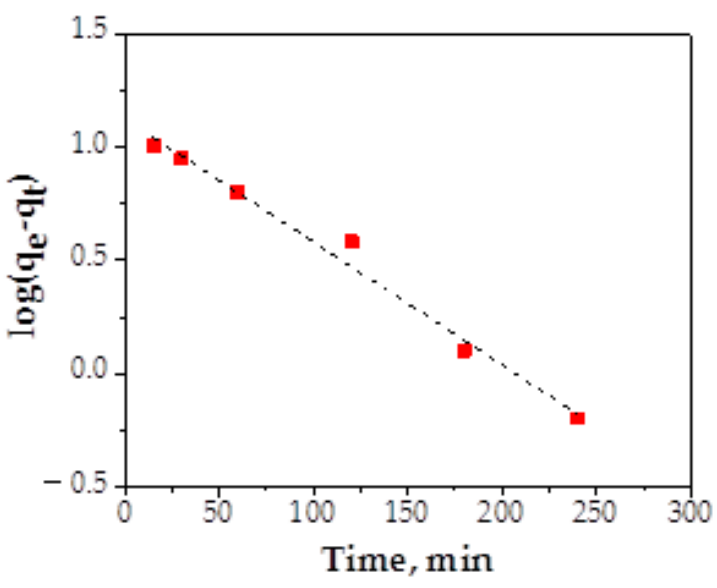

(a)

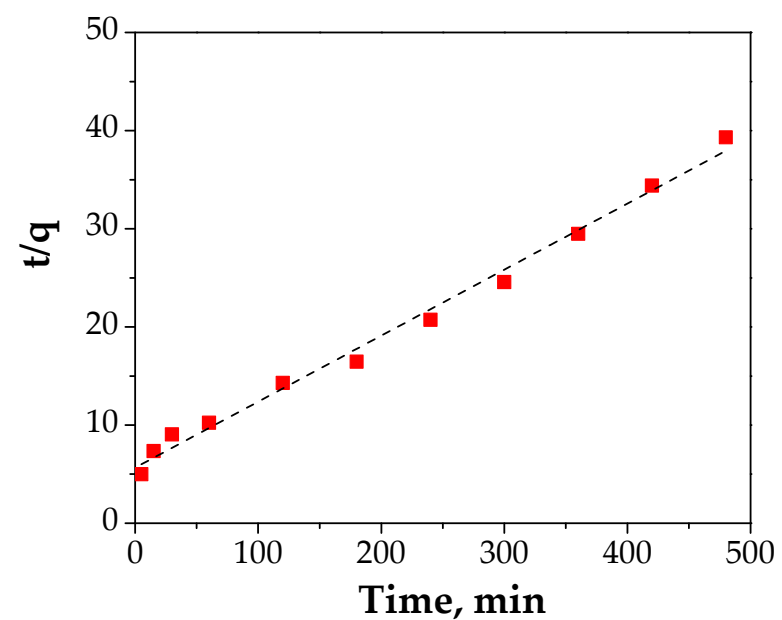

(b)

Figure 12. Kinetic adsorption plots: (a) pseudo-first-order model; (b) pseudo-second-order model.

Table 4. Kinetic parameters of $\mathrm{Cu}$ (II) adsorption onto $\mathrm{FA} / \mathrm{Fe}_{3} \mathrm{O}_{4}$.

\begin{tabular}{ccc}
\hline Kinetic Model & Parameters & Values \\
\hline \multirow{2}{*}{ Pseudo-first order } & $\mathrm{k}_{1}, 1 / \mathrm{min}$ & 0.0124 \\
& $\mathrm{R}^{2}$ & 0.9871 \\
\hline \multirow{2}{*}{ Pseudo-second order } & $\mathrm{q}_{\mathrm{e}} \mathrm{cal}, \mathrm{mg} / \mathrm{g}$ & 15.64 \\
& $\mathrm{k}_{2}, \mathrm{~g} / \mathrm{mg} \mathrm{min}$ & 0.00065 \\
& $\mathrm{R}^{2}$ & 0.993 \\
\hline
\end{tabular}

After applying the two kinetic models, it can be seen that the process of adsorption is described by the pseudo-second-order model. This fact indicated that the adsorption process of the $\mathrm{Cu}$ (II) ions onto $\mathrm{FA} / \mathrm{Fe}_{3} \mathrm{O}_{4}$ was complex and more than one mechanism was involved [12]. Also, the parameter of the initial adsorption rate when $\mathrm{t} \rightarrow 0 \mathrm{~h}$ was calculated using Equation (5).

$$
\mathrm{h}=\mathrm{k}_{2} \mathrm{q}_{\mathrm{e}}{ }^{2}
$$

The value obtained was $0.0969 \mathrm{mg} / \mathrm{g}$ min. 
These results suggested that the adsorption is predominantly chemical in nature.

Table 5 shows a comparison of the maximum adsorption capacities between the adsorbent prepared in this study and materials presented in the literature.

Table 5. Maximum Cu (II) adsorption capacities ( $\left.\mathrm{q}_{\max }\right)$.

\begin{tabular}{ccc}
\hline Adsorbent & qmax $\mathbf{( m g / g )}$ & References \\
\hline FA (Fly ash) & 14.46 & {$[15]$} \\
Fly ash treated with $5 \mathrm{M}$ of $\mathrm{NaOH}$ at $90{ }^{\circ} \mathrm{C}, 4 \mathrm{~h}$ & 27.904 & {$[15]$} \\
PPy/Perlite (Polypyrrole composite on perlite zeolite) & 3.57 & {$[49]$} \\
$\mathrm{ARH}$ (Bentonite treated with sodium) & 17.241 & {$[50]$} \\
$\mathrm{ARC}$ (Bentonite treated with calcium) & 18.181 & {$[50]$} \\
$\mathrm{ARS}$ (Bentonite treated with sulphuric acid) & 24.390 & {$[50]$} \\
Modified clay & $13-21$ & {$[51]$} \\
Natural zeolites & 2.5 & {$[14]$} \\
$\mathrm{Fe}_{3} \mathrm{O}_{4}$ particles with 1,6-hexadiamine & $25.77-26.58$ & {$[52]$} \\
Magnetic Prussian blue & 8.93 & {$[53]$} \\
FA/ $\mathrm{Fe}_{3} \mathrm{O}_{4}$ & 17.39 & This study \\
\hline
\end{tabular}

The $\mathrm{FA} / \mathrm{Fe}_{3} \mathrm{O}_{4}$ material obtained in this study presents a comparable or even higher adsorption capacity in comparison with other materials used for $\mathrm{Cu}$ (II) adsorption.

This research represents a preliminary investigation. Further work will be focused on the optimization of the process related to the $\mathrm{FA}-\mathrm{Fe}_{3} \mathrm{O}_{4}$ ratios and contact time, but also on the evaluation of the influence of ultrasonication applied at specific time points in order to disperse the particles aggregated during the adsorption process. The capacity of the magnetic composite to be magnetically separated from synthetic wastewater by using magnetic fields with different intensities and geometries will be also assessed.

\section{Conclusions}

An easy and simple method was used for the synthesis of a magnetic composite with fine adsorption properties. The effect of various variables, such as $\mathrm{FA} / \mathrm{Fe}_{3} \mathrm{O}_{4}$ dose, initial $\mathrm{Cu}$ (II) concentration, and contact time were investigated. From the obtained results, it can be concluded that these three parameters have an important influence on copper adsorption capacity. The synthesized material can be successfully used in large domains of the initial concentration of $\mathrm{Cu}$ ions in the wastewater $(100-700 \mathrm{mg} / \mathrm{L})$.

The results demonstrated that for fly ash/magnetite material, the adsorption capacity increases with about $20 \%$ compared with FA. Also, an important thing to note is that the maximum adsorption capacity was reached in $4 \mathrm{~h}$, while for FA the adsorption capacity attained the maximum value after $6 \mathrm{~h}$. This emphasizes that the insertion of $\mathrm{Fe}_{3} \mathrm{O}_{4}$ represents a clear advantage. The adsorption capacities are higher compared with natural zeolites and close to those of zeolites synthesized from FA, but the proposed method is very easy and cheaper.

Not least, this novel material represents progress that is opposite of other low-cost adsorbents for copper removal since it can be quickly removed by magnetic separation.

Langmuir Type 1 isotherm can predict the experimental data with a maximum adsorption capacity of $17.39 \mathrm{mg} / \mathrm{g}$. The $\mathrm{Fe}_{3} \mathrm{O}_{4}$ was inserted in the fly ash structure through the ball milling treatment and the material obtained did not break up into initial components.

Overall, it can be stated that this novel material represents a potentially low-cost adsorbent for copper removal, with improved adsorption capacity compared with the raw fly ash.

Author Contributions: Conceptualization, M.H., H.C. and G.B.; methodology, G.C., N.L. and G.B.; investigation, G.B., D.D.H., and M.H.; writing—original draft preparation, G.B. and G.C.; writingreview and editing, D.D.H., N.L., and M.H.; visualization, H.C.; supervision, M.H.; All authors have read and agreed to the published version of the manuscript. 
Funding: This research was funded by the UEFISCDI Agency through Project PN-III-P1-1.2-PCCDI2017-0152 (Contract No. 75PCCDI/2018).

Institutional Review Board Statement: Not applicable.

Informed Consent Statement: Not applicable.

Data Availability Statement: The data presented in this study are available on request from the corresponding author.

Acknowledgments: The authors gratefully acknowledge Maria Ignat for BET analysis.

Conflicts of Interest: The authors declare no conflict of interest.

\section{References}

1. Mehta, D.; Mazumdar, S.; Singh, S.K. Magnetic adsorbents for the treatment of water/wastewater-A review. J. Water Process. Eng. 2015, 7, 244-265. [CrossRef]

2. Yan, Y.; Liang, X.; Ma, J.; Shen, J. Rapid removal of copper from wastewater by Fe-based amorphous alloy. Intermetallics 2020, 124, 106849. [CrossRef]

3. Curteanu, S.; Buema, G.; Piuleac, C.G.; Sutiman, D.M.; Harja, M. Neuro-evolutionary optimization methodology applied to the synthesis process of ash based adsorbents. J. Ind. Eng. Chem. 2014, 20, 597-604. [CrossRef]

4. Taylor, A.A.; Tsuji, J.S.; Garry, M.R.; McArdle, M.E.; Goodfellow, W.L.; Adams, W.J.; Menzie, C.A. Critical review of exposure and effects: Implications for setting regulatory health criteria for ingested copper. Environ. Manag. 2020, 65, 131-159. [CrossRef]

5. Royer, A.; Sharman, T. Copper Toxicity. In Stat Pearls; Stat Pearls Publishing: Treasure Island, FL, USA, 2020.

6. Arbabi, M.; Golshani, N. Removal of copper ions Cu (II) from industrial wastewater: A review of removal methods. Int. J. Epidemiol. Res. 2016, 3, 283-293.

7. Liu, Y.; Wang, G.; Wang, L.; Li, X.; Luo, Q.; Na, P. Zeolite P synthesis based on fly ash and its removal of Cu (II) and Ni (II) ions. Chin. J. Chem. Eng. 2019, 27, 341-348. [CrossRef]

8. Vamvakidis, K.; Kostitsi, T.M.; Makridis, A.; Dendrinou-Samara, C. Diverse Surface Chemistry of Cobalt Ferrite Nanoparticles to Optimize Copper (II) Removal from Aqueous Media. Materials 2020, 13, 1537. [CrossRef]

9. Al-Saydeh, S.A.; El-Naas, M.H.; Zaidi, S.J. Copper removal from industrial wastewater: A comprehensive review. J. Ind. Eng. Chem. 2017, 56, 35-44. [CrossRef]

10. Benzaoui, T.; Selatnia, A.; Djabali, D. Adsorption of copper (II) ions from aqueous solution using bottom ash of expired drugs incineration. Adsorpt. Sci. Technol. 2018, 36, 114-129. [CrossRef]

11. Pavan Kumar, G.V.S.R.; Malla, K.; Yerra, B.; Srinivasa Rao, K. Removal of Cu (II) using three low-cost adsorbents and prediction of adsorption using artificial neural networks. Appl. Water Sci. 2019, 9, 44. [CrossRef]

12. Torres-Caban, R.; Vega-Olivencia, C.A.; Alamo-Nole, L.; Morales-Irizarry, D.; Roman-Velazquez, F.; Mina-Camilde, N. Removal of Copper from Water by Adsorption with Calcium-Alginate/Spent Coffee Grounds Composite Beads. Materials 2019, 12, 395. [CrossRef] [PubMed]

13. Zhang, X.; Shi, X.; Ma, L.; Pang, X.; Li, L. Preparation of Chitosan Stacking Membranes for Adsorption of Copper Ions. Polymers 2019, 11, 1463. [CrossRef] [PubMed]

14. Elboughdiri, $\mathrm{N}$. The use of natural zeolite to remove heavy metals $\mathrm{Cu}$ (II), $\mathrm{Pb}$ (II) and Cd (II), from industrial wastewater. Cogent Eng. 2020, 7, 1782623. [CrossRef]

15. Harja, M.; Buema, G.; Sutiman, D.M.; Munteanu, C.; Bucur, D. Low cost adsorbents obtained from ash for copper removal. Korean J. Chem. Eng. 2012, 29, 1735-1744. [CrossRef]

16. Noli, F.; Buema, G.; Misaelides, P.; Harja, M. New materials synthesized from ash under moderate conditions for removal of toxic and radioactive metals. J. Radioanal. Nucl. Chem. 2015, 303, 2303-2311. [CrossRef]

17. Bochkarev, G.R.; Kovalenko, K.A.; Pushkareva, G.I. Copper adsorption on Porozhinskoe manganese ore. J. Min. Sci. 2015, 51, 1029-1033. [CrossRef]

18. Tontisirin, S. Highly crystalline LSX zeolite derived from biosilica for copper adsorption: The green synthesis for environmental treatment. J. Porous Mater. 2015, 22, 437-445. [CrossRef]

19. Shen, X.; Qiu, G.; Yue, C.; Guo, M.; Zhang, M. Multiple copper adsorption and regeneration by zeolite 4A synthesized from bauxite tailings. Environ. Sci. Pollut. Res. 2017, 24, 21829-21835. [CrossRef]

20. Knight, A.W.; Tigges, A.B.; Ilgen, A.G. Adsorption of copper (II) on mesoporous silica: The effect of nano-scale confinement. Geochem. Trans. 2018, 19, 13. [CrossRef]

21. Bahaa, S.; Al-Baldawi, I.A.; Rasheed, S.; Abdullah, S.R.S. Biosorption of Heavy Metals from Synthetic Wastewater by Using Macro Algae Collected from Iraqi Marshlands. J. Ecol. Eng. 2019, 20, 18-22. [CrossRef]

22. Velasco-Garduño, O.; Martínez, M.E.; Gimeno, M.; Tecante, A.; Beristain-Cardoso, R.; Shirai, K. Copper removal from wastewater by a chitosan-based biodegradable composite. Environ. Sci. Pollut. Res. 2020, 27, 28527-28535. [CrossRef] [PubMed]

23. Li, H.; Chen, Y.; Cao, Y.; Liu, G.; Li, B. Comparative study on the characteristics of ball-milled coal fly ash. J. Therm. Anal. Calorim. 2016, 124, 839-846. [CrossRef] 
24. Harja, M.; Ciobanu, G. Eco-friendly Nano-adsorbents for Pollutant Removal from Wastewaters. In Handbook of Nanomaterials and Nanocomposites for Energy and Environmental Applications; Kharissova, O., Martínez, L., Kharisov, B., Eds.; Springer: Cham, Switzerland, 2020. [CrossRef]

25. Forminte, L.; Ciobanu, G.; Buema, G.; Lupu, N.; Chiriac, H.; Gomez de Castro, C.; Harja, M. New materials synthesized by sulfuric acid attack over power plant fly ash. Rev. Chim. 2020, 71, 48-58. [CrossRef]

26. Boycheva, S.; Zgureva, D.; Miteva, S.; Marinov, I.; Behunová, D.M.; Trendafilova, I.; Václaviková, M. Studies on the Potential of Nonmodified and Metal Oxide-Modified Coal Fly Ash Zeolites for Adsorption of Heavy Metals and Catalytic Degradation of Organics for Waste Water Recovery. Processes 2020, 8, 778. [CrossRef]

27. Buema, G.; Lupu, N.; Chiriac, H.; Roman, T.; Porcescu, M.; Ciobanu, G.; Burghila, D.V.; Harja, M. Eco-Friendly Materials Obtained by Fly Ash Sulphuric Activation for Cadmium Ions Removal. Materials 2020, 13, 3584. [CrossRef]

28. Supelano, G.I.; Cuaspud, J.G.; Moreno-Aldana, L.C.; Ortiz, C.; Trujillo, C.A.; Palacio, C.A.; Gómez, J.M. Synthesis of magnetic zeolites from recycled fly ash for adsorption of methylene blue. Fuel 2020, 263, 116800. [CrossRef]

29. Liu, X.; Hu, C.; Chu, L. Microstructure, Compressive Strength and Sound Insulation Property of Fly Ash-Based Geopolymeric Foams with Silica Fume as Foaming Agent. Materials 2020, 13, 3215. [CrossRef]

30. Kharissova, O.V.; Dias, H.R.; Kharisov, B.I. Magnetic adsorbents based on micro-and nano-structured materials. RSC Adv. 2015, 5, 6695-6719. [CrossRef]

31. Cao, J.; Wang, P.; Sun, Q. Green Synthesis of Magnetic Zeolite LTA using NaOH Activated Fly Ash. Z. Anorg. All. Chem. 2020, 646, 1666-1670. [CrossRef]

32. Jawad, A.H.; Malek, N.N.A.; Abdulhameed, A.S.; Razuan, R. Synthesis of Magnetic Chitosan-Fly Ash/Fe3O4 Composite for Adsorption of Reactive Orange 16 Dye: Optimization by Box-Behnken Design. J. Polym. Environ. 2020, 28, 1068-1082. [CrossRef]

33. Yamaura, M.; Fungaro, D.A. Synthesis and characterization of magnetic adsorbent prepared by magnetite nanoparticles and zeolite from coal fly ash. J. Mater. Sci. 2013, 48, 5093-5101. [CrossRef]

34. Sharma, M.; Kalita, P.; Senapati, K.K.; Garg, A. Study on Magnetic Materials for Removal of Water Pollutants. In Emerging Pollutants-Some Strategies for the Quality Preservation of Our Environment; Intech Open: London, UK, 2018; pp. 61-78.

35. Seracu, D.I. Handbook of Analytical Chemistry; Technic Publisher: Bucharest, Romania, 1989. (In Romanian)

36. Ghorpade, A.; Ahammed, M.M. Water treatment sludge for removal of heavy metals from electroplating wastewater. Environ. Eng. Res. 2018, 23, 92-98. [CrossRef]

37. Hashem, E.Y.; Seleim, M.M.; El-Zohry, A.M. Environmental method for spectrophotometric determination of copper (II). Green Chem. Lett. Rev. 2011, 4, 241-248. [CrossRef]

38. Karanac, M.; Đolić, M.; Veličković, Z.; Kapidžić, A.; Ivanovski, V.; Mitrić, M.; Marinković, A. Efficient multistep arsenate removal onto magnetite modified fly ash. J. Environ. Manag. 2018, 224, 263-276. [CrossRef]

39. Cretescu, I.; Harja, M.; Teodosiu, C.; Isopescu, D.N.; Chok, M.F.; Sluser, B.M.; Salleh, M.A.M. Synthesis and characterisation of a binder cement replacement based on alkali activation of fly ash waste. Process. Saf. Environ. Protect. 2018, 119, 23-35. [CrossRef]

40. Han, Z.; Zhang, Y.; He, P. One-Step Synthesis of Magnetic Zeolite from Zinc Slag and Circulating Fluidized Bed Fly Ash for Degradation of Dye Wastewater. J. Renew. Mater. 2020, 8, 405. [CrossRef]

41. Sutcu, M.; Erdogmus, E.; Gencel, O.; Gholampour, A.; Atan, E.; Ozbakkaloglu, T. Recycling of bottom ash and fly ash wastes in eco-friendly clay brick production. J. Clean. Prod. 2019, 233, 753-764. [CrossRef]

42. Sing, K.S. Reporting physisorption data for gas/solid systems with special reference to the determination of surface area and porosity. Pure Appl. Chem. 1985, 57, 603-619. [CrossRef]

43. Yildiz, S. Kinetic and isotherm analysis of $\mathrm{Cu}$ (II) adsorption onto Almond Shell (Prunus dulcis). Ecol. Chem. Eng. S 2017, 24, 87-106. [CrossRef]

44. Grande-Tovar, C.D.; Vallejo, W.; Zuluaga, F. Equilibrium and Kinetic Study of Lead and Copper Ion Adsorption on ChitosanGrafted-Polyacrylic Acid Synthesized by Surface Initiated Atomic Transfer Polymerization. Molecules 2018, 23, 2218. [CrossRef]

45. Yetilmezsoy, K.; Özçimen, D.; Koçer, A.T.; Majid Bahramian, M.; Kıyan, E.; Akbin, H.M.; Goncaloğlu, B.I. Removal of Anthraquinone Dye via Struvite: Equilibria, Kinetics, Thermodynamics, Fuzzy Logic Modeling. Int. J. Environ. Res. 2020, 14, 541-566. [CrossRef]

46. Buema, G.; Lupu, N.; Chiriac, H.; Ciobanu, G.; Kotova, O.; Harja, M. Modeling of solid-fluid non-catalytic processes for nickel ion removal. Rev. Chim. 2020, 71, 4-15. [CrossRef]

47. Mashhadi, S.; Javadian, H.; Ghasemi, M.; Saleh, T.A.; Gupta, V.K. Microwave-induced $\mathrm{H}_{2} \mathrm{SO}_{4}$ activation of activated carbon derived from rice agricultural wastes for sorption of methylene blue from aqueous solution. Desalin. Water Treat. 2016, 57, 21091-21104.

48. Costa, J.A.S.; Sarmento, V.H.V.; Romão, L.P.C.; Paranhos, C.M. Adsorption of organic compounds on mesoporous material from rice husk ash (RHA). Biomass Conv. Bioref. 2019. [CrossRef]

49. Naghizadeh, A.; Mousavi, S.J.; Derakhshani, E.; Sharifi, S.M. Fabrication of polypyrrole composite on perlite zeolite surface and its application for removal of copper from wood and paper factories wastewater. Korean J. Chem. Eng. 2018, 35, 662-670. [CrossRef]

50. Belhadri, M.; Sassi, M.; Bengueddach, A. Preparation of Economical and Environmentally Friendly Modified Clay and Its Application for Copper Removal. J. Water Chem. Technol. 2019, 41, 357-362. [CrossRef] 
51. Jabłońska, B.; Busch, M.; Kityk, A.V.; Huber, P. Natural and Chemically Modified Post-Mining Clays-Structural and Surface Properties and Preliminary Tests on Copper Sorption. Minerals 2019, 9, 704. [CrossRef]

52. Hao, Y.M.; Man, C.; Hu, Z.B. Effective removal of $\mathrm{Cu}$ (II) ions from aqueous solution by amino-functionalized magnetic nanoparticles. J. Hazard. Mater. 2010, 184, 392-399. [CrossRef]

53. Uogintè, I.; Lujanienè, G.; Mažeika, K. Study of $\mathrm{Cu}$ (II), Co (II), Ni (II) and Pb (II) removal from aqueous solutions using magnetic Prussian blue nano-sorbent. J. Hazard. Mater. 2019, 369, 226-235. [CrossRef] 